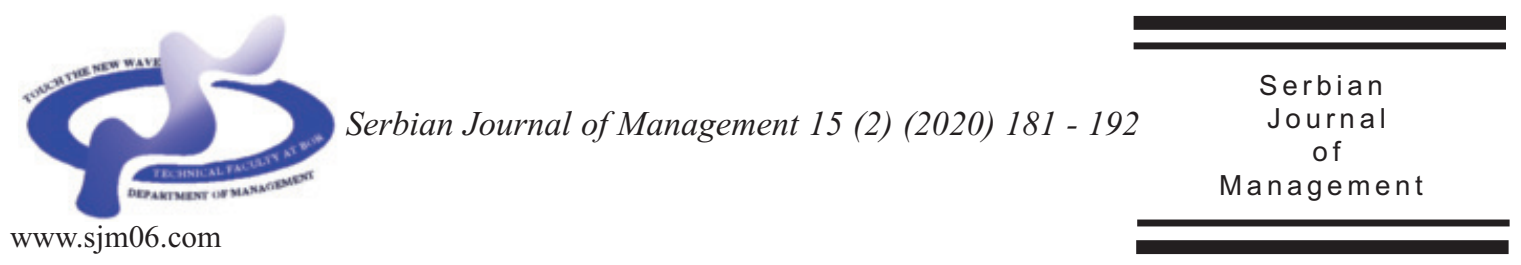

\title{
EXAMINING THE FACTORS INFLUENCING ADOPTION OF E-BANKING SERVICES IN CHENNAI CITY
}

\author{
N. Akbar Jana, Radha Mohan Chebolu ${ }^{a}$, A. K. Subramani ${ }^{\text {b* }}$ and M. S. Sasikalac

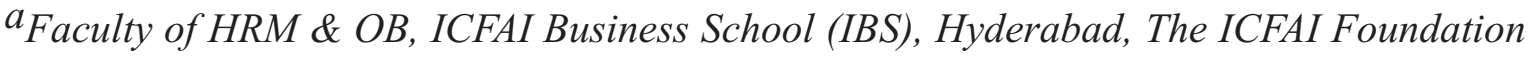 \\ for Higher Education (IFHE) Hyderabad, Telangana - 501203. India

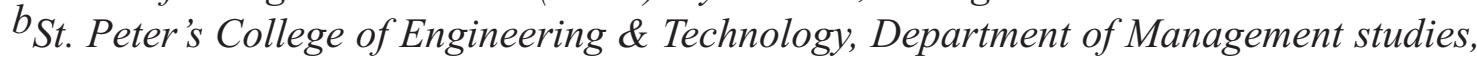 \\ Avadi, Chennai - 600054, India \\ ${ }^{c}$ Acharya Institute of Graduate Studies, Department of Commerce, Acharya Dr. S \\ Radhakrishnan Road, Soladevanahalli,Achit Nagar Post, Bengaluru 560-107, India
}

(Received 28 January 2019; accepted 28 June 2019)

\begin{abstract}
India being a developing country still has millions of people who prefers to have traditional branch banking system rather than e-banking. The reason behind their preference is either they hesitate or they don't have sufficient knowledge about the e-banking services. The purpose of this study is to examine the relationship between perceived usefulness, perceived barriers, customer attitude, and perceived effectiveness of adoption of e-banking services. An effective number of responses of 470 respondents from both public and private banks' customers were used to examine the hypothesized relationships. Structural equation modelling are performed to test the constructs and their relationships. The study found that there is a direct relationship between perceived usefulness and technology adoption in developing customer attitude toward adoption of e-banking services; whereas, there is no relationship between perceived barriers and technology adoption. The sample size and potential respondents from a selected region of the study may limit its wider applicability and generalization.
\end{abstract}

Keywords: technology adoption, perceived usefulness, perceived barriers, perceived effectiveness, ebanking services, structural equation modelling

\section{INTRODUCTION}

In past decade, there has been a rapid growth in the adoption of e-banking or internet-

banking services among customers;
however, there has been considerable proportion of customers who still carry out banking transactions in the traditional way

\footnotetext{
*Corresponding author:draksubramani@gmail.com
}

DOI: $10.5937 /$ sjm 15-20323 
(Alsajjan \& Dennis, 2010). The global banking industry has been undergone various transformations in the recent decades. The ebanking technology enables customers to avail banking services' anywhere, anytime, and anyway. This has prompted banks to embrace technology to meet increasing customers' expectation and market competition (Afshan et al., 2018).

Now-a-days, both public and private banks are delivering banking-related services through electronic channels to the customers, but there are customers who don't have awareness or hesitate to make use of ebanking services such as mobile banking or internet banking (Fawzy \& Esawai, 2017). Banks offer e-banking services to their customers such as account opening, fund transfer, bill payment, and etc. Recently, ebanking has become very attractive to both customers and banks because technology behind e-banking services plays a major role in understanding and processing the humantechnology interface and utility (Chaouali et al., 2016). Despite the fact that several studies available literature related to customers' adoption of e-banking services but very few studies explore the relationship between perceived usefulness, perceived effectiveness, perceived barriers, and customer attitude towards adoption of ebanking services (Alwan \& Al-Zubi, 2016; Afshan et al., 2018; Rahi et al., 2019; Siyal et al., 2019). Hence, the study aims to address the following research questions (RQs) as stated below:

RQ1: What are the key factors influencing the adoption of technology in ebanking services?

RQ2: What are the relationship exists between the key factors influencing the adoption of technology in e-banking services?

\section{THEORETICAL BACKGROUND AND HYPOTHESES DEVELOPMENT}

\subsection{Perceived usefulness and customer attitude}

According to Davis (1989), the perceived usefulness is 'consumers' perceptions regarding the outcome of the experience". Further, it can be defined as the extent to which a person deems a particular system to boost his/her job performance (Venkatesh et al., 2003). Moreover, Pikkarainen et al. (2004) found that perceived usefulness as a determinant of actual behavior which encourages user to adopt technology in the technology acceptance framework. Cheng et al. (2006) provide support for the relationship between perceived usefulness and adoption of e-banking services. Past studies provide empirical evidence for the positive relationship between perceived usefulness and customer attitude toward adoption of e-banking services (Alawan et al., 2016; Chaouali et al., 2016; Masoud \& Taqa, 2017; Afshan et al., 2018; Rahi et al., 2019; Siyal et al., 2019; Agarwal et al., 2009). Hence, the following hypothesis (H1) is stated as:

H1: Perceived usefulness and customer attitude toward adoption of e-banking services are positively related.

\subsection{Perceived barriers and customer attitude}

Customers' resistance to innovations have been explained through different barriers that 
inhibit or prevent the adoption of an innovation (Bauer \& Hein, 2006; Laukkanen, 2016). It consists of functional barriers and psychological barriers. Usage, value, and risk constitute functional barriers, whereas tradition and image refer to psychological barriers. The importance of security and privacy for the acceptance of ebanking services have been well noted in several studies conducted in banking sector. Moreover, it was found that lack of privacy and security were found to be significant obstacles to the adoption of e-banking services. Past studies provide empirical evidence for the negative relationship between perceived barriers and customer attitude toward adoption of e-banking services and hence, the following hypotheses (H2) are developed as (Bauer \& Hein, 2006; Kuisma et al., 2007; Laukkanen, 2016; Afshan et al., 2018; Rahi et al., 2019; Siyal et al., 2019):

H2a: Perceived barriers and customer attitude toward adoption of e-banking services are negatively related.

H2b: Perceived barriers and customer attitude toward adoption of e-banking services are negatively related but mediated by perceived usefulness.

\subsection{Perceived barriers and perceived usefulness}

Studies indicate that psychological barriers play a major role in determining the resistance towards adoption of e-banking services than actual usage and value. Moreover, the findings highlight the role of self efficacy in customers' risk perceptions toward e-banking services. Both functional and psychological barriers inhibit adoption of e-banking services which arise from several sources such as service infrastructure, technical, security, social and cultural, and customer orientation (Kuisma et al., 2007). Past studies provide empirical evidence for the negative relationship between perceived barriers and perceived usefulness toward adoption of e-banking services (Alawan et al., 2016; Chaouali et al., 2016; Laukkanen, 2016; Masoud \& Taqa, 2017; Afshan et al., 2018; Rahi et al., 2019; Siyal et al., 2019). Hence, the following hypothesis $(\mathrm{H} 3)$ is stated as:

H3: Perceived barriers and perceived usefulness toward adoption of e-banking services are negatively related.

\subsection{Perceived usefulness and technology adoption}

Studies on technology acceptance model (TAM) suggest that technology adoption is determined by intention to use, perceived usefulness, and perceived ease of use of the system (Davis, 1989; Venkatesh et al., 2003). Whereas, Liao and Cheung (2002) adopted an alternative research approach which assumes that technology adoption is determined by intention to perform. The key attributes of perceived usefulness are accuracy, security, network speed, userfriendliness, user involvement, and convenience. Past studies provide empirical evidence for the positive relationship between perceived usefulness and technology adoption of e-banking services and hence, the following hypotheses (H4) are developed as (Alawan et al., 2016; Fawzy \& Esawai, 2017; Masoud \& Taqa, 2017; Afshan et al., 2018; Rahi et al., 2019; Siyal et al., 2019): 
H4a: Perceived usefulness and technology adoption of e-banking services are positively related.

H4b: Perceived usefulness and technology adoption are positively related but mediated by customer attitude towards adoption of e-banking services.

\subsection{Perceived barriers and technology adoption}

The degree of risk associated with customers' perception about technology and its usage that significantly affect the adoption of e-banking services (Nasri \& Charfeddine, 2012). On the other hand, introducing a new technology may involve both benefits and risks to the user that significantly affect the adoption of new technology (Kuisma et al., 2007). Al-Somali et al. (2009) found that level of education, trust, and resistance to change have significant impact on customer attitude towards adopting of e-banking services. Past studies provide empirical evidence for the negative relationship between perceived barriers and technology adoption of ebanking services and hence, the following hypotheses (H5) are framed as (Laukkanen, 2016; Fawzy \& Esawai, 2017; Masoud \& Taqa, 2017; Afshan et al., 2018; Rahi et al., 2019; Siyal et al., 2019):

H5a: Perceived barriers and technology adoption of e-banking services are negatively related.

H5b: Perceived barriers and technology adoption are negatively related but mediated by customer attitude towards adoption of ebanking services.

\subsection{Customer attitude and technology adoption}

In general, individuals who buy a product/service analyze the perceived benefits and risks associated with the product/service. Similarly, customers who adopt e-banking services also analyze the perceived usefulness and risks associated with the technology and its services (Laforet \& Li, 2005; Laukkanen, 2016). Alsajjan \& Dennis (2010) observed that customer attitude plays an important role in adoption of e-banking services beside trust and perceived usefulness. Past studies provide empirical evidence for the positive relationship between customer attitude and technology adoption of e-banking services and hence, the following hypothesis (H6) is developed as (Alwan \& Al-Zubi, 2016; Fawzy \& Esawai, 2017; Rahi et al., 2019; Siyal et al., 2019; Afshan et al., 2018):

H6: Customer attitude and technology adoption of e-banking services are positively related.

\subsection{Technology adoption and perceived effectiveness}

Customers who adopting e-banking services would evaluate its effectiveness in terms of information accuracy, transaction speed, user friendliness, convenience, features availability, and etc., (Venkatesh et al., 2003; Laukkanen, 2016). Hence, the following hypothesis $(\mathrm{H} 7)$ is framed in order to verify the linkage between adoption of ebanking services and perceived effectiveness and stated as (Venkatesh et al., 2003; Pikkarainen et al., 2004; Laukkanen, 2016; Fawzy \& Esawai, 2017; Afshan et al., 2018; Rahi et al., 2019; Siyal et al., 2019): 
H7: Technology adoption and perceived effectiveness of e-banking services are positively related.

\subsection{The conceptual framework}

Based on the literature review, the conceptual framework is developed (Ahmad, 2018). The conceptual framework consists of five key variables such as perceived usefulness, perceived barriers, customer attitude, technology adoption, and perceived effectiveness. Figure 1 depicts the conceptual framework of the study.

\section{RESEARCH METHODOLOGY}

\subsection{Survey instrument}

An empirical study was designed to examine relationship between perceived usefulness, perceived barriers, customer attitude, and perceived effectiveness of adoption of e-banking services. The survey instrument developed based on past studies conducted in the context of e-banking services. Table 1 provides the details of study constructs. The survey instrument consists of four sections. Section 1 is about demographic profile such as age, gender, occupation, e-banking usage, and period of usage. Section 2 is about perceived usefulness of adopting e-banking services that consists of factors and their items related to comfortability, ease of use, trust and security, social influence, and internet experience. Section 3 is about perceived barriers of adopting e-banking services that consists of factors and their items related to infrastructural barrier, technical barrier, security barrier, social and cultural barriers, and personal barrier. Section 4 is about customer attitude, technology adoption, and perceived effectiveness of adopting ebanking services. The scales were adopted from past studies to obtain responses in a 5point Likert scale which varies from strongly disagree to strongly agree.

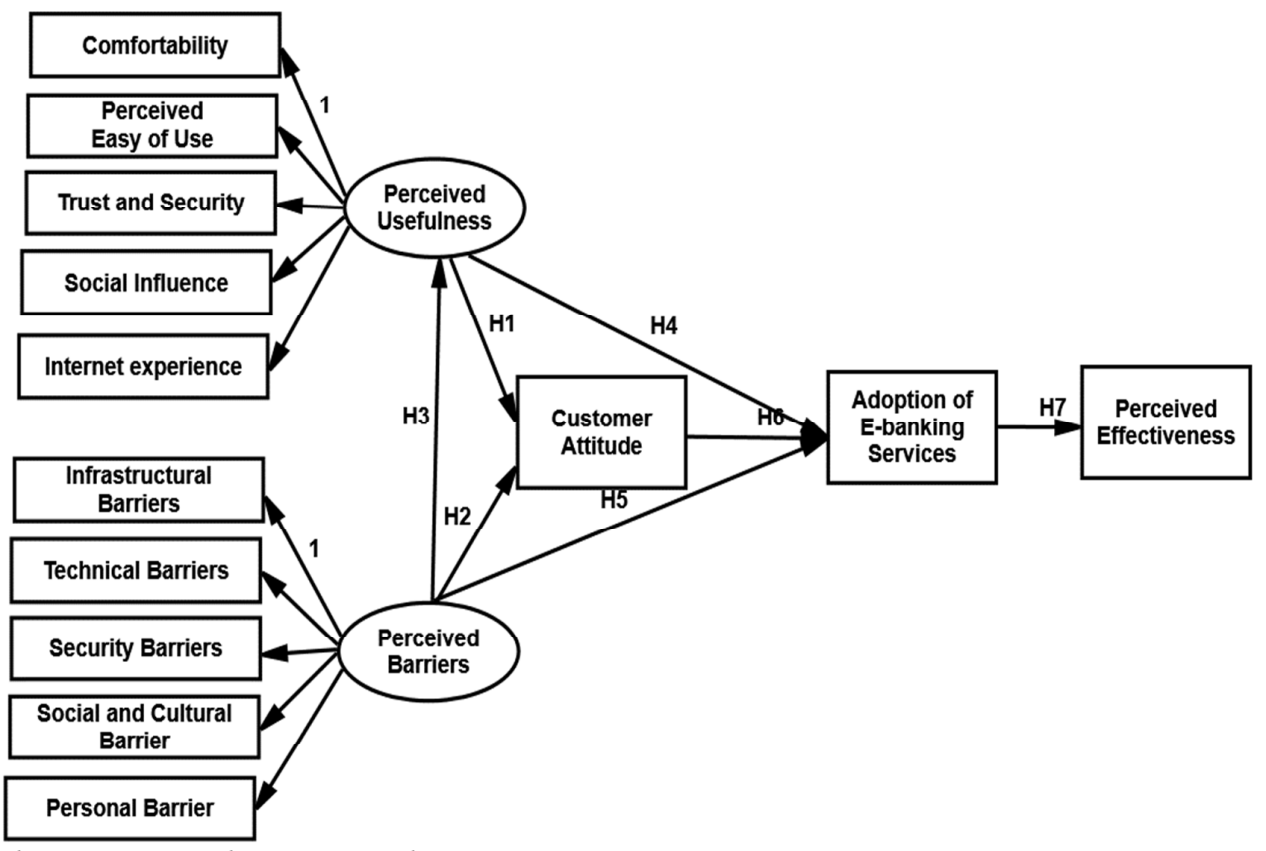

Figure 1. The Conceptual Framework 


\subsection{Sampling framework and data} collection

The sampling framework of the study is restricted to customers' from both public and private banks located in Chennai. India. A self-administered online survey was conducted to obtain data from customers who use e-banking services from public or private banks. An effective number of responses was 470 samples after conduction of data collection process.

\section{DATA ANALYSIS AND FINDINGS}

The structural equation modelling (SEM) approach is followed to examine the hypothesized relationships between perceived usefulness, perceived barriers, customer attitude, and perceived effectiveness of adoption of e-banking services (Hair et al., 2006). Descriptive statistics of sample profile is described.

\subsection{Demographic profile}

Demographic profile of the respondents include respondents' age, gender, occupation, banking sector, and e-banking usage period. The sample respondents are from both public and private banks. An effective number of responses was 470 respondents. About $78 \%$ of the respondents were below 35 years of age and $64 \%$ of the respondents were males. About $60 \%$ of the respondents were working in jobs related to private sector. Nearly $51 \%$ of the respondents were having banking account in public sector banks. About 56\% of the respondents were using e-banking services between last 1 to 5 years.

\subsection{Structural equation modelling}

The average values of item scores in each factor are used as a measure (or indicator) for the underlying construct. PU has five factors and hence, five indicators $(\mathrm{CB}, \mathrm{EU}, \mathrm{TS}, \mathrm{SI}$, and IE) are used to measure the key factors influencing the perceived usefulness of ebanking services. Similarly, PBS has five factors and hence, five indicators (IB, TB, $\mathrm{SB}, \mathrm{SCB}$, and $\mathrm{PB}$ ) are used to measure the key factors influencing the perceived barriers in using e-banking services. The maximum likelihood estimation (MLE) method is used to estimate the model parameters in the structural model using AMOS 20.0. The structural model is shown in Figure 2. The structural (or path) model provides a good fit to the data. The model fit indices are given

Table 1. The Constructs used in the study

\begin{tabular}{ll}
\hline Constructs & Past Studies \\
\hline Perceived Barriers (PBS) & Bauer \& Hein (2006); Kuisma et al. (2007); Laukkanen (2016) \\
Customer Attitude (CA) & Liao \& Cheung (2002); Venkatesh et al. (2003); Laforet \& Li \\
& (2005); Guriting \& Ndubisi (2006) \\
Technology Adoption (TA) & Rakhi \& Mala (2014); Afshan et al. (2016); Alwan \& Al-Zubi \\
& (2016); Chaouali et al. (2016); Laukkanen (2016); Fawzy \& \\
& Esawai (2017); Masoud \& Taqa (2017) \\
Perceived Effectiveness (PE) & Venkatesh et al. (2003); Pikkarainen et al. (2004) \\
\hline
\end{tabular}


below. The overall goodness of fit for the structural model is acceptable (Chi-squared statistic/degrees of freedom $=2.683, \mathrm{df}=245$, p-value $>0.05 ; \quad$ RMSEA $=0.060 ; \quad R M R=$ $0.033)$. Goodness of fit index $(\mathrm{GFI}=0.886)$ and adjusted goodness of fit index (AGFI= 0.860 ) are greater than 0.80 indicate that the model provides a good fit. The comparative fit index $(\mathrm{CFI}=0.962)$ and Tucker-Lewis index $(\mathrm{TLI}=0.957)$ are greater than 0.90 indicate that the structural model provides good support to proceed with the hypotheses tests.

\subsection{Results of hypotheses tests}

The relationships between perceived usefulness, perceived barriers, and customer attitude toward adoption of e-banking services are examined using standardized coefficients (or weights) in the hypothesized structural (or path) model. Figure 2 shows the structural relationships between the constructs. The results of hypotheses tests are provided in Table 2 and discussion is given below.
H1. Relationship between perceived usefulness and customer attitude

The standardized regression weight is 0.946 which is significant at $1 \%$ level of significance $(p$-value $<0.01)$ and indicates that perceived usefulness (PU) and customer attitude (CA) are positively related. Moreover, the key factors contributing to perceived usefulness of e-banking services and other factors explain about $90.3 \%$ of variation in customer attitude. Hence, hypothesis (H1) is supported.

\section{H2. Relationship between perceived barriers and customer attitude}

The standardized regression weight is 0.031 which is not significant at $10 \%$ level of significance ( $p$-value $>0.10$ ) and indicates that perceived barriers (PBS) and customer attitude (CA) are not directly related. Hence, hypothesis $(\mathrm{H} 2 \mathrm{a})$ is not supported. However, considering perceived usefulness (PU) as a mediating variable, the relationship between perceived barriers and customer attitude are

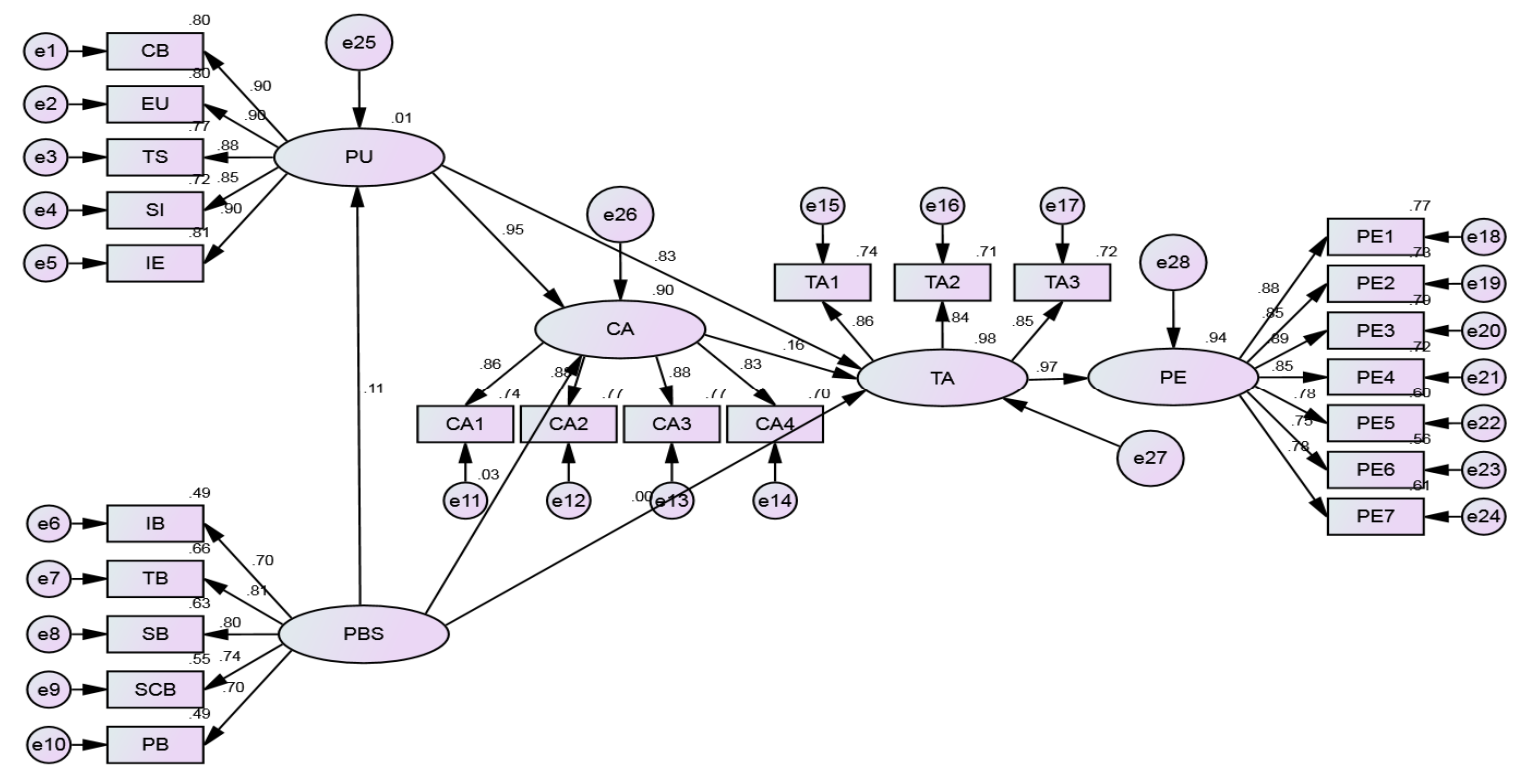

Figure 2. The Structural Model 
Table 2. Results of Structural Model (Direct, Indirect, and Total Effects)

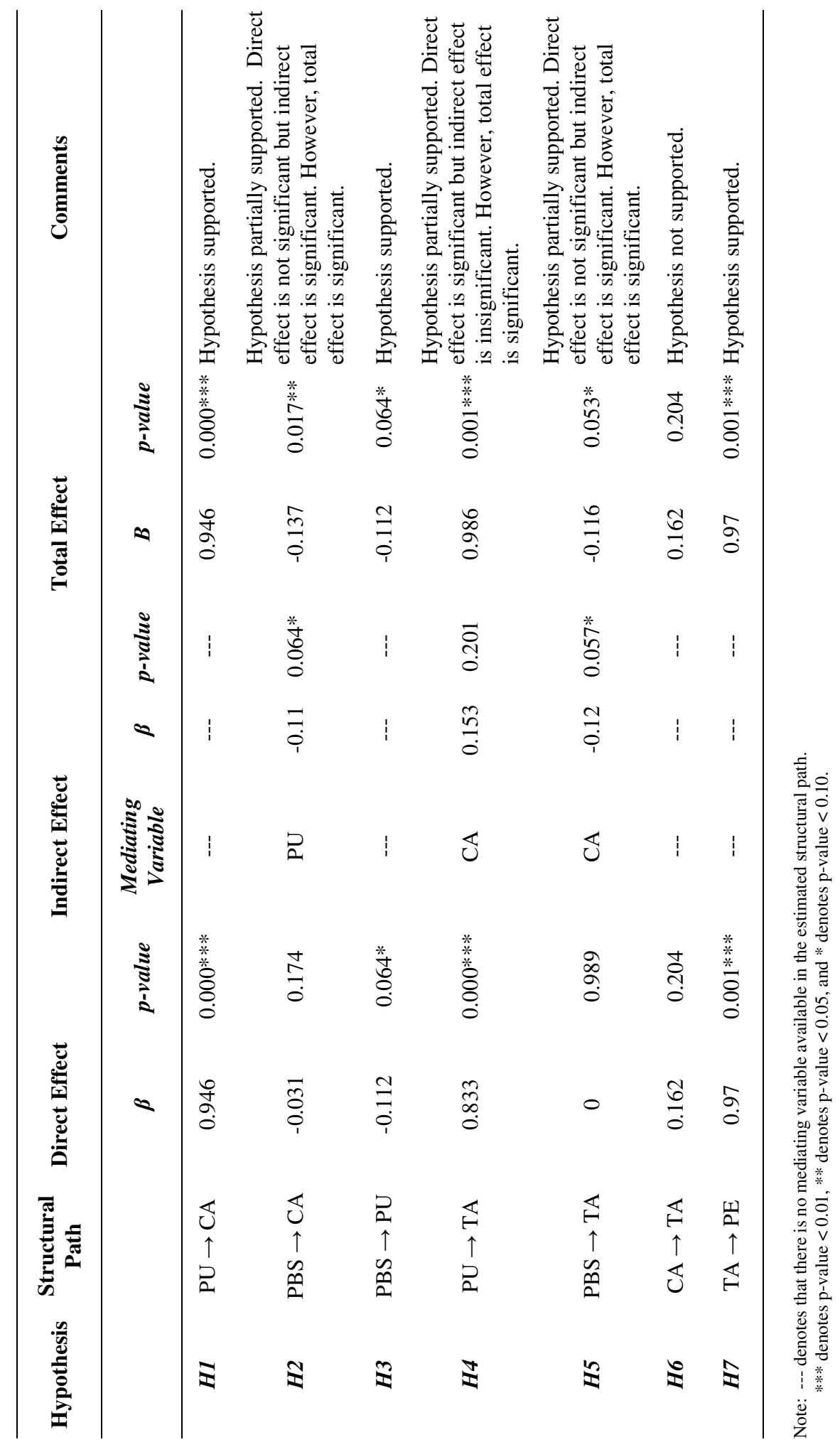


negatively related. The standardized regression weight is -0.106 which is significant at $10 \%$ level of significance (pvalue $<0.10$ ) and indicates that perceived barriers and customer attitude are indirectly related. Moreover, the key factors contributing to perceived barriers of ebanking services and other factors explain about $90.3 \%$ of variation in customer attitude. Hence, hypothesis (H2b) is supported.

\section{H3. Relationship between perceived barriers and perceived usefulness}

The standardized regression weight is 0.112 which is significant at $10 \%$ level of significance ( $p$-value $<0.10)$ and indicates that perceived barriers (PBS) and perceived usefulness (PU) are negatively related. Moreover, the key factors contributing to perceived barriers of e-banking services explain only about $1.3 \%$ of variation in perceived usefulness. Hence, hypothesis (H3) is supported.

H4. Relationship between perceived usefulness and technology adoption

The standardized regression weight is 0.833 which is significant at $1 \%$ level of significance $(p$-value $<0.01)$ and indicates that perceived usefulness (PU) and technology adoption (TA) are positively related. Moreover, the key factors contributing to perceived usefulness and other factors explain about $97.5 \%$ of variation in adoption of e-banking services. Hence, hypothesis (H4a) is supported. However, considering customer attitude (CA) as a mediating variable, the relationship between perceived usefulness and technology adoption are not related. The standardized regression weight is 0.153 which is not significant at $10 \%$ level of significance $(\mathrm{p}$-value $<0.10)$ and indicates that perceived usefulness and technology adoption are not indirectly related. Hence, hypothesis $(\mathrm{H} 4 \mathrm{~b})$ is not supported.

\section{H5. Relationship between perceived barriers and technology adoption}

The standardized regression weight is 0.000 which is not significant at $10 \%$ level of significance ( $\mathrm{p}$-value $>0.10$ ) and indicates that perceived barriers (PBS) and technology adoption (TA) are not directly related. Hence, hypothesis (H5a) is not supported. However, considering customer attitude (CA) as a mediating variable, the relationship between perceived barriers and technology adoption are negatively related. The standardized regression weight is -0.115 which is significant at $10 \%$ level of significance ( $p$-value $<0.10)$ and indicates that perceived barriers and technology adoption are indirectly related. Moreover, the key factors contributing to perceived barriers and other factors explain about $97.5 \%$ of variation in adoption of e-banking services. Hence, hypothesis ( $\mathrm{H} 5 \mathrm{~b}$ ) is supported.

\section{H6. Relationship between customer attitude and technology adoption}

The standardized regression weight is 0.162 which is not significant at $10 \%$ level of significance ( $p$-value $<0.10)$ and indicates that customer attitude (CA) and technology adoption (TA) are not related. Moreover, customer attitude and other factors explain about $97.5 \%$ of variation in adoption of ebanking services. Hence, hypothesis (H6) is not supported. 
H7. Relationship between technology adoption and perceived effectiveness

The standardized regression weight is 0.970 which is significant at $1 \%$ level of significance $(\mathrm{p}$-value $<0.01)$ and indicates that technology adoption (TA) and perceived effectiveness (PE) are related. Moreover, technology adoption and other factors explain about $94.1 \%$ of variation in perceived effectiveness of e-banking services. Hence, hypothesis $(\mathrm{H} 7)$ is supported.

\section{CONCLUSION}

Banking sector in India has witnessed remarkable innovation in digitization and offers e-banking services to the customers at large. The understanding of customers' attitude toward adoption of e-banking services become more prominent in designing and delivering the banking-related operations and services. The study developed a theoretical framework to examine the relationship between perceived usefulness, perceived barriers, customer attitude, and perceived effectiveness toward adoption of e-banking services in the Indian context considering both public and private sector banks. The structural equation modelling approach is followed to examine the hypothesized relationship. The results show that the importance of perceived barriers and perceived usefulness in developing customers' attitude toward adopting ebanking services and its effectiveness. Hence, the study has some potential to identify and describe the key factors and their relationship towards adoption of ebanking services.

This study develops and examines a unique conceptual framework for technology adoption in the context of e-banking services that principally consists of perceived usefulness, perceived barriers, customer attitude, and perceived effectiveness. The study contributes to the body of technology adoption literature by examining the relationship between perceived usefulness, perceived barriers, customer attitude, and perceived effectiveness toward adoption of e-banking services. Despite the fact that several studies available literature related to customers' adoption of e-banking services but very few studies explore the relationship between perceived usefulness, perceived barriers, customer attitude, and perceived effectiveness toward adoption of e-banking services. Hence, technology managers can consider the key factors identified in the study while designing and developing ebanking operations and transactions for their customers. For example, there is a direct relationship between perceived usefulness and technology adoption in developing customer attitude toward adoption of ebanking services; whereas, there is no relationship between perceived barriers and technology adoption. The sample size and potential respondents from a selected region of the study may limit its wider applicability and generalization. Hence, future study can aim to examine the theoretical framework with larger sample size and wider representation of the respondents. Future study can identify other factors and their relationship within the theoretical framework may add value to the present study. 


\title{
ИСПИТИВАЊЕ ФАКТОРА КОЈИ УТИЧУ НА ПРИХВАТАҢЕ УСЛУГА Е-БАНКАРСТВА У ГРАДУ ЧЕНАЈ
}

\author{
N. Akbar Jan, Radha Mohan Chebolu, A. K. Subramani, M. S. Sasikala
}

\section{Извод}

Индија као земља у развоју још увек има милионе људи који предност дају традиционалном филијалном банкарском систему, него електронском банкарству. Разлог за њихову преференцију је што они или оклевају или немају довољно знања о услугама е-банкарства. Сврха ове студије је да испита однос између уочене корисности, уочених баријера, става клијента и перципиране ефикасности усвајања услуга е-банкарства. За испитивње хопотетизираних односа коришћени су одговори 470 испитаника, клијената, како јавних тако и приватних банака. Ради испитивања конструката и њихових односа извршено је моделирање структуралних једначина. Студија је открила да постоји директна веза између уочене корисности и усвајања технологије у развијању ставова клијента према усвајању услуга ебанкарства; док не постоји веза између перципираних баријера и усвајања технологије. Величина узорка и потенцијални испитаници из одабраног региона студије могу ограничити његову ширу применљивост и уопштавање.

Кључне речи: усвајање технологије, уочена корисност, уочене баријере, перципирана ефикасност, услуге електронског банкарства, моделовање структуралних једначина

\section{References}

Afshan, S., Sharif, A., Waseem, N., \& Frooghi, R. (2018). Internet banking in Pakistan: an extended technology acceptance perspective. International Journal of Business Information Systems, 27 (3), 383410.

Ahmad, M. (2018). Review of the technology acceptance model (TAM) in internet banking and mobile banking. International Journal of Information Communication Technology and Digital Convergence, 3 (1), 23-41.

Alawan, A.A., Dwivedi, Y.K., Rana, N.P.P., \& Williams, M.D. (2016). Consumer adoption of mobile banking in Jordan: examining the role of usefulness, ease of use, perceived risk and self-efficacy. Journal of Enterprise Information Management, 29 (1), 118-139.
Alsajjan, B., \& Dennis, C. (2010). Internet banking acceptance model: crossmarket examination. Journal of Business Research, 63 (9-10), 957-963.

Alwan, H.A., \& Al-Zubi, A.I. (2016). Determinants of internet banking adoption among customers of commercial banks: an empirical study in the Jordanian banking sector, International Journal of Business and Management, 11 (3), 95-104.

Al-Somali, S.A., Gholami, R., \& Clegg, B. (2009). An investigation into the acceptance of online banking in Saudi Arabia. Technovation, 29 (2), 130-141.

Bauer, K., \& Hein, S.E. (2006). The effect of heterogeneous risk on the early adoption of internet banking technologies. Journal of Banking \& Finance, 30 (6), 1713-1725.

Chaouali, W., Yahia, I.B., \& Souiden, N. (2016). The interplay of counter-conformity motivation, social influence, and trust in 
customers' intention to adopt internet banking services: the case of an emerging country. Journal of Retailing and Consumer Services, 28 (C), 209-218.

Cheng, T.C.E., Lam, D.Y.C., \& Yeung, A.C.L. (2006). Adoption of internet banking: an empirical study in Hong Kong. Decision Support Systems, 42 (3), 1558-1572.

Davis, F.D. (1989). Perceived usefulness, perceived ease of use, and user acceptance of information technology. MIS Quarterly, 13 (3), 319-340.

Fawzy, S.F., \& Esawai, N. (2017). Internet banking adoption in Egypt: extending technology acceptance model. Journal of Business and Retail Management Research, 12 (1), 109-118.

Guriting, P., \& Ndubisi, N.O. (2006). Borneo online banking: evaluating customer perceptions and behavioural intention. Management Research News, 29 (1/2), 6-15.

Hair, Jr. J.F., Black, W.C., Babin, B.J., Anderson, R.E., \& Tatham, R.L. (2006). Multivariate Data Analysis. Person Prentice Hall, 6th edition, Upper Saddle River, New Jersey, NJ.

Heranadez, J.M.C., \& Mazzon, J.A. (2007). Adoption of internet banking: proposition and implementation of an integrated methodology approach. International Journal of Bank Marketing, 25(2), $72-88$.

Kuisma, T., Laukkanen, T., \& Hiltunen, M. (2007). Mapping the reasons for resistance to internet banking: a means-end approach. International Journal of Information Management, 27 (2), 75-85.

Laforet, S., \& Li, X. (2005). Consumers' attitudes towards online and mobile banking in China. International Journal of Bank Marketing, 23 (5), 362-380.

Laukkanen, T. (2016). Consumer adoption versus rejection decisions in seemingly similar service innovations: the case of the internet and mobile banking. Journal of Business Research, 69 (7), 24322439.

Liao, Z., \& Cheung, M.T. (2002). Internet-based e-banking and consumer attitudes: an empirical study. Information and Management, 39 (4), 283-295.

Masoud, E., \& Taqa, H.A. (2017). Factors affecting customers' adoption of e-banking services in Jordan. Information Resources Management Journal, 30 (2), 44-60.

Nasri, W., \& Charfeddine, L. (2012). Factors affecting the adoption of internet banking in Tunisia: an integration theory of acceptance model and theory of planned behavior. The Journal of High Technology Management Research, 23 (1), 1-14.

Pikkarainen, T., Pikkarainen, K., Karjaluoto, H., \& Pahnila, S. (2004). Consumer acceptance of online banking: an extension of the technology acceptance model. Internet Research, 14 (3), 224-235.

Rahi, S., Abd.Ghani, M., \& Ngah, A.H. (2019). Integration of unified theory of acceptance and use of technology in internet banking adopting setting: evidence from Pakistan. Technology in Society, (58), 101120.

Siyal, A.W., Ding, D., \& Siyal, S. (2019). M-banking barriers in Pakistan: a customer perspective of adoption and continuity intention. Data Technologies and Applications, 53 (1), 58-84.

Venkatesh, V., Morris, M.G., Davis, G.B., \& Davis, F.D. (2003). User acceptance of information technology: toward a unified view. MIS Quarterly, 27 (3), 425-478. 